\title{
A Comparative Examination of Career and Start-up Expectations in South Korea, Ukraine, and the United States
}

\author{
Sherrie E. Human, Thomas Clark,
} Charles H. Matthews, Julie Stewart, and Candace Gunnarsson

\begin{abstract}
$\boldsymbol{R}$ elatively few comparative studies have examined bow perceptions across cultures might converge or diverge regarding careers in general and new ven-
\end{abstract} ture careers in particular. Our research addresses this gap by providing a comparative study of career perceptions among undergraduate business students in three countries with different levels of experience with capitalism: Ukraine, South Korea, and the United States. Results suggest both surprising differences and interesting similarities between undergraduate students in the three countries with regard to bow they perceive characteristics associated with entrepreneurial careers. Findings are discussed in the context of distinct differences and commonalities across cultures and implications for future research provided.

Keywords: career intentions, perceptions, cross-cultural, entrepreneurial careers, international context, entrepreneurship pedagogy

In the past two decades, scholars have examined issues related to career expectations in general (Dominitz and Manski 1996;Ajzen 1985) and entrepreneurial career expectations in particular (Scherer, Brodzinski, and Wiebe 1990; Brenner, Pringle, and Greenhaus 1991; Boyd and Vozikis 1994; Parasuraman et al. 1996; Segal, Borgia, and Schoenfeld 2002). Research indicates that role models (Cooper and Dunkelberg 1984; Cooper 1986; Holland 1983; Katz 1992; Krueger 1993; Timmons 1986); gender (Aldrich 1989; work experience (Scott and Twomey 1988; Matthews and Moser 1995; Kolvereid 1996); self monitoring behavior (Kilduff and Day 1994); entrepreneurial drive (Florin, Karri, and Rossiter 2007); and cultural values (Dahles 2005), to name a few, are important factors affecting entrepreneurial career choice. Importantly, scholars have also acknowledged limitations of prediction models regarding entrepreneurial career choice, particularly models that focus primarily on antecedents of entrepreneurial careers. Instead, they call for examining a wider range of issues in addition to antecedents that may influence career choices (Katz 1988; Reynolds 1995), and for taking a more explorative approach when examining complex issues such as how cultural values may influence entrepreneurial careers or activity (Autio et al. 1997; Autio et al.
2001). Consequently, models that describe a progression process beyond antecedents, such as career socialization and orientation issues, have become useful frameworks for advancing our knowledge of entrepreneurial careers (Dyer 1994; Katz 1992; Sinclair 2008).

Our study extends this stream of research on entrepreneurial career choice in two ways. First, we examine and compare student expectations of careers and entrepreneurship across three country contexts (South Korea, Ukraine, and United States) that differ on a variety of dimensions suggested as important for entrepreneurship activity.This type of comparison is important, given the increasing interest in entrepreneurship education globally-and particularly in developing countries. Second, we focus our examination on issues that include both antecedents (e.g., national context and issues beyond antecedents), comparing the important process topics of career socialization and career orientation (Dyer 1994). Few comparative studies have examined these issues across country contexts and cultures, so our goals are to help advance scholarship and guide educators' pedagogy.

Our study is guided by three compelling questions:

1. What are the career expectations in general, and entrepreneurship career expectations in particular, of university students in South Korea, Ukraine, and the United States?

2. How will these expectations vary across these national contexts?

3. What are the implications of these expectations for entrepreneurship educators?

Scholars have acknowledged the challenges and limitations of assigning to individuals the cultural values identified at a national level (Shane 1995; Tiessen 1997). Consequently, the focus of our study is to examine and compare career socialization and career orientation issues across country contexts and to suggest implications these have for entrepreneurship educators and scholars, not to predict entrepreneurial career choice based on particular country-specific antecedents.

Given the acknowledged complexity of prediction models of entrepreneurial career choice (Reynolds 1995; Autio et al. 1997; Zhao, Seibert, and Hills 2005; Lewis and Lancaster 2007) and the need for examination of a wider range of 
career socialization and career orientation issues related to entrepreneurial career choice, we adopt an explorative rather than a predictive approach regarding our constructs of interest (Wayne et al. 1999). In the following section, we provide a brief literature review, both of the country contexts and our constructs of interest. Then, we present our findings and discussion.

\section{Literature Review}

Our study is guided by conceptual frameworks outlined by Dyer (1994), Katz (1992), and others who describe the entrepreneurial career process and the impact of country context on that process (Hayton et al. 2002). In particular, we adopt Dyer's (1994) model of entrepreneurial careers as our conceptual framework, as it highlights career antecedents, career socialization, career orientation, and career progression issues. As mentioned earlier, scholars have focused attention on identifying important antecedents, such as cultural values, that influence entrepreneurial careers and entrepreneurial activity. Our study explores the two processes in Dyer's model beyond antecedents: career socialization and career orientation, and on describing how these two sets of issues vary across country context. Thus, we first include in our literature discussion an overview of the three national contexts-South Korea, United States, and Ukraine - highlighting selected literature relevant for understanding entrepreneurial careers and entrepreneurial activity in those contexts (Table 1). We then describe our methodology, the results and their implications for entrepreneurial education.

\section{National Contexts South Korea}

South Korea has 48.1 million people, with about 80 percent living in urban areas.About 16 percent of the labor force is in agriculture, more than one third works in mining and manufacturing, the rest is involved in service occupations (Salter et al. 2000). The country's real GDP per capita is $\$ 20,499$ (Heritage 2007).

In addition to its strong exports of automobiles, textiles, electronics, shoes, iron and steel, and its shipbuilding industry, South Korea, with the world's 13th largest economy (Ramstad 2007), has developed a reputation for IT excellence. Formed in the mid-1950s, the capitalist economy of the country has been heavily dependent on relationships with the United States and Japan and large investments from those countries as well. Most of South Korea's wealth has traditionally been in the hands of about 15 gigantic, interlocking conglomerates called chaebols. These firms have employed the majority of South Korea's working population and owned most of the banks.

Also important to its strengthening economy are the availability of an increasingly skilled Korean labor force as well as the skills of South Koreans receiving higher education abroad and at home. In fact, the country has the world's highest number of Ph.D.s per capita. South Koreans have been determined to have one of the world's strongest work ethic among all nations studied by the International Labor Organization, averaging more than 2,400 hours of work per year (Webb 2001).

One of Asia's success stories, South Korea has been characterized as an "Asian Tiger" enjoying a strong economic growth rate of up to 10 percent annually in the mid-1990s. The country's high-speed development stopped and then reversed in 1998 as Asia's spreading economic crisis hit the country. A number of economic reforms were put into place to help reverse a depression, including restructuring of the way business was conducted. To address and maintain the impetus for the country's economic growth, the government implemented measures to develop small business enterprises. For entrepreneurs with technical competitiveness, creative ideas, and who wanted to start businesses, the Small Business Start-up Promotion Act was enacted in January 1986. The Small Business Fundamental Act and the Act on Restructuring of Small Industries were also established to provide assistance in the formation and growth of small businesses. The Korea Federation of Small Business, a quasigovernmental agency composed of representatives of all trade association cooperatives, has also been very active in con-

\begin{tabular}{|l|l|l|l|l|l|l|l|}
\hline \multicolumn{9}{|c|}{ Table 1. Country Comparison Data } \\
\hline Country & Population & $\begin{array}{l}\text { per Capita } \\
\text { GDP }\end{array}$ & $\begin{array}{l}\text { Establishment } \\
\text { of Capitalist } \\
\text { Economy }\end{array}$ & $E F^{a}$ & $C^{b}$ & $E D B^{c}$ & $E^{b} B^{c}$ \\
\hline Ukraine & $48 \mathrm{M}$ & $\$ 6,394$ & $1990 \mathrm{~s}$ & 53 & 2.7 & 145 & 128 \\
\hline South Korea & $48 \mathrm{M}$ & $\$ 20,499$ & $1950 \mathrm{~s}$ & 68.6 & 5.1 & 23 & 126 \\
\hline United States & $293 \mathrm{M}$ & $\$ 39,676$ & Late 1700s & 81.9 & 7.2 & 3 & 6 \\
\hline
\end{tabular}

a. $\mathrm{EF}=$ Index of Economic Freedom, Heritage Foundation, 2007 (higher score means more economic freedom)

b. $\mathrm{CI}=$ Corruption Index, Transparency International, 2006 (higher score means less corruption).

c. $\mathrm{EDB}=$ Ease of Doing Business \& ESB = Ease of Starting a Business, World Bank 2008 (rank of 181 countries, lower score means easier to do business and to start a business). 
ducting business research on venture start-ups.

Results of the Global Entrepreneurship Monitor 2000 research (Reynolds et al.2000) indicate that South Korea is in the top three of the 21 countries examined in terms of rate of entrepreneurship. That is, as many as one in seven adults are involved in some sort of entrepreneurial activity, the second highest rate after Brazil.Approximately 5 percent of the adult population directly invests in new business start-ups, scoring second among all the GEM 2000 countries after the United States. ${ }^{1}$ The adoption of a more Western individualistic orientation would make sense, especially for younger generations who have grown up in a Korea closely aligned socially, economically and politically with the United States. Thus, the South Korean social and economic context represents an interesting dichotomy; on the one hand historically valuing interdependence, and on the other hand, valuing and developing a strong entrepreneurial culture typically associated with independence. Particularly in the past two decades, South Korea has established an infrastructure of educational and financial institutions to actively promote entrepreneurship, capitalism, and a free market economy. South Korea scores 68.6 , a ranking of 36 , and categorized as "moderately free," on the Heritage Foundation Index of Freedom (2007). It scores 5.1 , or 43 , in the Corruption Perception Index (Transparency International 2006)

The World Bank survey ranked South Korea 126 of 181 countries for ease of starting a business, a significant contrast to its rank of 23 in ease of doing business (World Bank 2008).

\section{United States}

Physically, the United States is the fourth largest country and its population (about 293 million) is the third largest in the world. Nearly 80 percent of Americans live in metropolitan areas and the real GDP per capita is \$39,676 (Heritage 2007). The country's economic strength is based on such things as a diversified industrial and service sectors, investment abroad, and the dollar as the major world currency. Although the service sector employs more people than manufacturing, the United States remains a world leader in industry and high technology. As a demand-driven consumer society, the country exports capital goods, cars, consumer goods, food and machinery (Salter et al. 2000). The United States has the strongest work ethic among major industrialized nations, trailing only the workers in the developing economies of South Korea and Czech Republic among all nations studied (Webb 2001). Reynolds et al. (2000) found that the U.S. entrepreneurial activity prevalence rate is 12.7 percent, the third highest of the 21 countries studied, behind Brazil and South Korea.

One in every 15 adults in the United States invests in new business start-ups, the highest private investor rate among all the GEM Study countries. Further, the U.S. culture of entre- preneurship is deeply rooted: entrepreneurial role models are celebrated, failure is seen as a learning experience and a "resume builder," and both intrapreneurial and entrepreneurial career paths are highly regarded. Even when working on a team,Americans often think in terms of several distinct individuals blending their efforts rather than a group working as one unit. Thus, the United States' context has clearly supported independent careers, individualism, and entrepreneurship for several centuries. The Heritage Foundation categorized the U.S. economy as free, scoring it 81.9, or 4 of 180 countries evaluated, on the Index of Economic Freedom (2007). The United States scores 7.2, or 20th, on the 2006 Corruption Perception Index. The country scores third in ease of doing business and sixth in ease of starting a business in the World Bank's survey (2008).

\section{Ukraine}

Formerly part of the Soviet Union, the Ukraine achieved independence from Moscow in 1991. With more than 47 million people-68 percent living in urban areas-the republic's population is almost as large as that of the United Kingdom and France. Distribution of employment by sector is 56 percent industrial, 25 percent services, and 19 percent agriculture. The country's primary industries include aircraft, aerospace technology, shipping, turbines, tractors and other heavy industries (Salter et al. 2000). The real GDP per capita for the country is $\$ 6,394$ (Heritage 2007). Until the early 1990s, the Ukraine was governed as part of the USSR, with government-dictated industrial policies. Scholars describe Russian managers' tendency to rely more on networking and politicking to rise within their hierarchies than they do on more traditional U.S. measures such as quantity and quality of production (Luthans, Rosenkrantz, and Welsh 1992). Kaufmann, Welsh, and Bushmarin (1995) found that Russian respondents possessed lower internal locus of control scores, suggesting that individuals in former Soviet states expect more external motivations for change than U.S. respondents who have more internal motivations for change.

Studies specifically focusing on Ukrainian respondents found that unlike their U.S. respondents, they avoided uncertainty and were less individualistic (Abetti, Hirvensalo, and Kapuj 1998). Spector et al. (2001) found that Ukrainian managers placed more value on collectivism than individualism in business; the former a value that reflects interdependence, viewing oneself as part of a network of social groups in contrast to independence, motivated primarily by one's own goals and preferences. Despite a wealth of resources that led to the country's title of "Breadbasket of Europe," the Ukrainian economy has suffered since the nation's independence. Researchers have determined that the Ukraine economy had the largest unofficial or "extra legal" economy of all 14 countries in the former Soviet Union and Central and 
Eastern Europe (East European Markets 1997; Kristoff 2003). Crime and bureaucratic corruption continues, and the common practice of blat-political connections or influence, well greased with bribe money-results in "shamelessly blackmailed private businessmen ... where any action by a private enterprise would easily be interpreted as a violation of the new laws" (Akchurin 1992; Harris 1995; Johnson 2008). In short, the social and economic context of Ukraine has not been supportive of independent careers and a free market economy, even though officially sanctioned since 1991 (Abetti, Hirvensalo, and Kapuj 1998; Luthans, Rosenkrantz, and Welsh 1992). Likewise, the infrastructures to support entrepreneurial activity are only beginning to emerge more than a decade later.

The 2007 Heritage Foundation Index of Economic Freedom, assigned the Ukraine a 53.35 score on a $0-100$ scale, with 100 being 100 percent free. With still extensive state ownership of industry and services and privatization only recently underway, it was categorized as having a "mostly unfree" economy (Heritage 2007). The Ukraine scored 2.7 out of $10.0,123$ out of 180 countries on Transparency International's 2006 Corruption Perception Index (Transparency International 2006). For perspective, this indicates continuing corruption issues, as a score of 5.0 or below "is the number Transparency International considers the borderline figure distinguishing countries that have ... a serious corruption problem." A recent visitor commented that "Ukraine has a workforce for whom a sense of entrepreneurship has been snuffed out by decades of socialism....Theft is endemic.... Bribes grease the wheels of bureaucracy and get some things done, but bribes can be used against you as well"(Johnson 2008). A recent poll of Ukrainian citizens conducted by the Horshenin Institute indicated most view the police and courts as the most corrupt forces in the country (Ukrainian News Agency 2008).

In the World Bank Doing Business survey, Ukraine ranked 145 out 181 economies in the category of Ease of Doing Business and 128 out of 181 economies in its Ease of Starting a Business annual evaluation, reflecting a poor climate for both external investment and for entrepreneurial enterprise (World Bank 2008).

In summary, the context for our three student respondent groups varied dramatically not only in terms of early and recent history, but also in terms of individual, social, and economic antecedents that influence entrepreneurial career choice. Given such differences, these three countries provide rich contexts for our study of career socialization and career orientation.

\section{Conceptual Development}

Our study is guided, in part, by Dyer's (1994) model of entrepreneurial careers, and in particular, we focus on career socialization and orientation issues that Dyer describes, respectively, as "socialization experiences that would prepare someone to choose to be an entrepreneur," and "how individuals orient themselves to the role of an entrepreneur" (p.11). Since a student population is necessarily limited in its range of experiences that would prepare them for entrepreneurship, we further defined these constructs for purposes of our study as "what are students' career and business experiences and related expectations?" (career socialization) and "how do students identify with start-up roles and beliefs?" (career orientation).

In this next section of the literature review, we describe our constructs of interest which we identified by scanning major topics of interest to both entrepreneurship scholars and educators and that related to career choice issues beyond antecedents. We selected seven important topics that, while not comprehensive, are commonly investigated in the literature (e.g., Sexton and Landstrom 2000) and frequently discussed in entrepreneurship classrooms (e.g., Kuratko 2007; Kuratko and Hodgetts 1995). We categorized three of these topics-career preparation, career success factors, and business failure factors-as conceptually consistent with Dyer's career socialization construct, as they examined students' career and business experiences and related expectations. We categorized four of our constructs-career expectations, start-up motivations, start-up team orientation and start-up riskiness - as conceptually consistent with Dyer's career orientation construct since they tapped the issue of how students identify with start-up roles and beliefs. In the following sections we briefly discuss literature on each construct of interest.

\section{Career Socialization Career Preparation}

Models of career education across disciplines include preparation activities such as education and work experience as important precursors to entrepreneurial career selection (e.g.,Ajzen 1985; Dyer 1994; Moore 2002). Research findings that past and current behaviors are predictors of future behaviors have led U.S. colleges and universities to emphasize obtaining practical experience and implementing behavior-based career preparation techniques before graduation (Clark 2000; Van Clieaf 1991) so that students can communicate about work and academic experiences in ways that will make them attractive to future employers.

P1a: Students from countries with short-term experience with capitalism will emphasize education over work experience.

Alternatively, we posit:

P1b: Students from countries with short-term experience with capitalism will emphasize work experience over education. 


\section{Career Success Factors}

Scholars have examined career success factors that range from individual to social to organization factors (Miner 1990). For instance, O'Reilly and Chatman (1994), Wayne et al. (1999), Furnham (1992), and Crant (1996) found that individual-level motivation, skills, and abilities were important precursors to career success. Further, Stephens, Szajna, and Broome (1998) found that expectations were important antecedents to success; Friedman, Kane, and Cornfield (1998) identified external social networks as important for career success; and Chay (1993) and Aryee et al. (1994) identified important organization-individual fit antecedents to success. Kauffman, Welsh, and Bushmarin (1995) identify locus of control and Kilduff and Day (1994) self-monitoring behavior as other individual variables that impact entrepreneurial success.

P2a: Students from countries with short-term experience with capitalism will perceive internal factors as more important for career success, while those from countries with moderate- or long-term experience with capitalism will perceive that both internal and external factors are important to career success.

Alternatively, we posit:

P2b: Students from traditionally collectivist countries will perceive external factors as more important for career success and students from traditionally individualist countries will perceive internal factors as more important for career success.

\section{Business Failure Factors}

Interest in new venture failure as a formal area of study and discussion in classrooms has increased in the recent past, evidenced by the inclusion of the subject heading "failure or failure/survival" since 2001 in the Frontiers of Entrepreneurship Research, Proceedings of Babson Entrepreneurship Research Conference. Scholars have investigated important variables for business success versus failure both in the United States and across national contexts (Lussier 1995; Lussier and Pfeifer 2001). Potential factors leading to failure (vs. success) include individual-level issues such as experience and education and organizational-level issues such as economics, planning, and marketing. From the perspective of doing business with third-world economies, new issues, such as organized crime, corruption, and government regulations and taxes, have also come to the forefront (Tayler 2001) as relevant for venture survival. Samuel Huntington argues that Americans in particular misunderstand corruption in developing economies. From his perspective, modernization of economies and corruption historically has gone hand in hand, often as ways of overcoming unresponsive bureaucracies (cited in Kaplan 2001). Recent evidence of unethical business practices in developing nations, such as toys paint- ed with lead paint and milk contaminated with melamine from China, as well as furniture makers using radioactive Belarusian timber cut near the site of Chernobyl meltdown, support Huntington's position.

P3a: Students from all three countries will perceive more market-based reasons (e.g., lack of demand) for new venture failure.

Alternatively, we posit:

P3b: Students from countries with short-term experience with capitalism will perceive more nonmarketbased reasons (e.g., taxes, crime for new venture failure), while students from countries with moderate to long-term capitalism experience will perceive more market-based reasons (e.g., lack of demand for new venture failure).

\section{Career Orientation Career Expectations}

A number of comparative studies have examined career expectations or employment status choice decisions (Katz 1992) for working in different organizational contexts, from starting a business to working for a small or large company to working for a governmental organization (Matthews and Moser 1995; Goddard and Weihe 1992; Scott and Twomey 1988). Brenner, Pringle, and Greenhaus (1991) and Kolvereid (1996) found that students' career preferences differed from their beliefs about the actual likelibood or expectations of working in particular organizational contexts. While some scholars suggest that intentions are a useful predictor of who will select an entrepreneurial career (Krueger and Brazeal 1994), others argue that intentions may have limited usefulness in predicting future entrepreneurial behaviors due to the strong influence of situational factors (Reynolds 1995).

P4a: Students' expectations for new venture versus organizational careers will vary significantly based on their country's experience with capitalism. Specifically, students from countries with moderate or longterm experience with capitalism will have greater expectations regarding the likelihood of new venture careers over organizational careers than students from countries with short-term experience with capitalism.

Alternatively, we posit:

P4b: Students' expectations for new venture versus organizational careers will vary significantly based on the value placed in their countries on individualism versus collectivism. Specifically, students from historically collectivist countries will perceive more likelihood of working for large or medium-sized companies or the government while students from historically individualist countries will perceive more likelihood of working for a small company or starting their own business. 


\section{New Venture Motivations}

Motivations for starting a new venture have been the subject of both scholarly and practitioner work for more than a decade (see review by Carter, Gartner, and Shaver 2004). Indeed, scholars and practitioners in both textbooks and trade books frequently outline key motivations or reasons why individuals start businesses such as money, social approval, or independence (Cooper, Woo, and Dunkelberg 1989; Timmons 1999; Lee and Wong 2004). A conceptual framework for new venture motivations developed by Alange and Scheinberg (1988) and Scheinberg and MacMillan (1988) and summarized by Carter, Gartner, and Shaver (2004) highlights five typical reasons found in the literature for why entrepreneurs start a new venture: material incentives, personal values or norms, social approval, independence, and avoidance of negative situations.

P5a: Students from countries with different levels of capitalism experience or with differing values placed on collectivism versus individualism will have similar perceptions of what motivates entrepreneurs to start new ventures.

Alternatively, we posit:

P5b. Students from countries with different levels of capitalism experience or with differing values placed on collectivism versus individualism will have dissimilar perceptions of what motivates entrepreneurs to start new ventures.

\section{Start-up Team Orientation}

Scholars have shown that a team orientation versus an individual orientation has a positive impact on future venture success (Chandler and Lyon 2001; Hyatt 1989). In addition, entrepreneurship textbooks and practitioner books emphasize the importance of entrepreneurs taking a serious look at their founding team composition before making selections, including size and type of individuals on the team (Kuratko 2007; Abrams 2004).

P6a: Students from countries with short-term experience with capitalism will perceive the starting a business alone as more likely than starting a business with a team, while students from countries with moderateand long-term capitalism experience will perceive starting a business with a team as more likely.

Alternatively, we posit:

P6b: Students from traditionally collectivist countries will perceive starting a business alone as less likely then starting a business with a team, while students from traditionally more individualist countries will perceive starting a business alone as more likely.

\section{Start-up Riskiness}

A primary assumption in entrepreneurship research and edu- cation has been the risk associated with starting a new venture. Scholars and practitioners describe risk assessment both in terms of objective financial analysis such as market or financial risk, and in terms of subjective analysis such as personal risk (Forlani and Mullin 2000; Reid and Smith 2003; Sykes and Dunham 1995). Scholars have also examined perceived risk in terms of how individuals are likely to react to setbacks during the entrepreneurial process (Cardon and McGrath 1999), and to what or to whom these setbacks are attributed (Cave, Eccles, and Rundle 2001).

P7a: Students from countries with long-term experience with capitalism will perceive new ventures as less risky than students from countries with low- and moderate-term capitalism experience.

Alternatively, we posit:

P7b: Students from traditionally collectivist countries will perceive new ventures as less risky than students from historically individualist countries.

\section{Methodology}

A total of 371 business students participated in this study, 169 from Ukraine, 133 from South Korea, and 69 from the United States. A questionnaire was developed, drawing on the constructs and literature described above. More specifically, for career preparation we selected "work experience" from Dyer's (1994) set of socialization topics, and added perceptions of success and failure as other topics that would be influenced by students' socialization experiences up to that point. For career success factors, due to the wide range of factors identified in the literature, we selected a set that included important characteristics such as internal and external factors and acquired skills or knowledge. For business failure, we chose four key success/failure factors from the Lussier and Pheifer's (2001) review of the literature that represent important individual, organizational, and market related issues and that are frequently cited in the practitioner literature (Kuratko and Hodgetts 2004). We added to this set two questions relevant to doing business with third-world economies: organized crime and government taxes and regulations (Kaplan 2001; Tayler 2001). For career expectations, we adopted the four factors identified by Scott and Twomey (1988), and added a fifth factor of "working for a medium-size company" since this might be relevant in different national contexts. For start-up motivations, we adopted the five types identified by Carter, Gartner, and Shaver (2001) as commonly found in the literature. Finally, since start-up riskiness, like career success, has a wide range of definitions, we developed our set of questions based on key themes in the literature related to risk (e.g., personal risk, business risk). See Figure 1 for a list of final questionnaire items.

The questionnaire was first developed in English and a pilot test was initially administered to U.S. students at a mid- 
size private, urban university in the Midwest. Once the survey was refined, it was translated into Korean and Ukrainian by Korean and Ukrainian students, respectively, studying for a year at Xavier University. The back-translation validation methodology followed or suggested by previous authors (Moore 1989) was adopted in which we used Korean and Ukrainian individuals unassociated with our original survey translations to translate the Korean and Ukrainian language surveys back to English, then we compared the back-translated English versions with the original English version. This methodology helped validate the accuracy of the survey translations and ensure that respondents across countries were answering comparable questions. Pilot surveys were administered to a small group of U.S., South Korean and Ukrainian students prior to full implementation of the questionnaire.

After the pilot test process, the U.S. questionnaires were administered to business undergraduates enrolled in an Introduction to Management course at Xavier. The South Korean and Ukrainian questionnaires were administered onsite in their respective countries to undergraduates in similar introductory business management courses at Pusan and Karkhiv State universities, respectively, by the same Korean and Ukrainian graduate students who helped develop and translate the questionnaire at the U.S.-based university. Undergraduate respondents were advised verbally and in writing that participation was voluntary. Student volunteers were asked to fill out a 28-question survey, which contained demographic and Likert-scale items pertaining to career perceptions, in general, and perceptions of start-up careers, in particular. We indicated their identity would remain anonymous. Surveys were administered in class, with the result being a 100 percent response rate from all classes.

\section{Results}

\section{Sample}

The students from all three countries were fairly homogenous in terms of age and level of education. The overall average age was approximately 21 years with a standard deviation of 2.33 years. The Ukrainian students were the youngest with an average age of 19.7. All students had completed a high school degree or equivalent within the past four years of pursuing a college degree in business. The ratio of male to female students in the U.S. sample was 3 to 1 , in the Korean sample 2 to 1 , and in the Ukrainian sample male and female students were fairly equally represented (44\% and 56\%, respectively).

Tables 2 through 8 present means, standard deviations, and corresponding $\mathrm{F}$ statistics for each country by the seven constructs of interest. F tests were calculated to determine significant differences in the means across the countries. Mean responses are presented in Tables 2 through 8, using a results presentation methodology of rank-ordering the means (e.g., Golhar and Deshpande 1997) to help facilitate country comparisons.

\section{Discussion and Implications for Entrepreneurship Educators Career Preparation}

Table 2 illustrates that U.S. students reported working nearly 11 months at a permanent or full-time job and working for roughly four companies so far, while the Ukrainian students reported working at a full-time job for 3.44 months at roughly two companies, and South Korean students reported working 2.14 months at one company so far. In addition,American students reported an average workweek of 17 hours, while Korean and Russian students reported workweeks of 5 hours and 6 hours, respectively. Table 2 also illustrates that Ukrainian students reported studying the longest with nearly 40 hours per week devoted to class or preparing for classes, Korean students in the middle with 28 hours of weekly study and class time, and U.S. students reported studying the least with 10 hours per week devoted to class and class preparation.

In short, U.S. students emphasize work experience over academic preparation, while the reverse is the case for Korean and Ukrainian students (Table 2). In terms of seeing how their educations apply to real-world issues, Ukrainian and South Korean students might do well to imitate their American counterparts in developing paid and unpaid internship programs with local businesses and nonprofit organizations. Such experiences can help a student understand a field of business better, get a foot in the door on a job after college,

\begin{tabular}{|l|r|r|r|r|r|r|r|}
\hline \multicolumn{7}{|c|}{ Table 2. Career Preparation/Experience } \\
\hline Question & \multicolumn{1}{|c|}{ United States } & \multicolumn{1}{|c|}{ Korea } & \multicolumn{4}{c|}{ Ukraine } \\
\hline & Mean & \multicolumn{1}{|c|}{ SD } & Mean & \multicolumn{1}{|c|}{ SD } & Mean & SD & F \\
\hline Months worked at a full-time job & 10.62 & 23.98 & 2.14 & 7.65 & 3.44 & 9.1 & $10.54^{* *}$ \\
\hline Number of companies worked for & 3.82 & 2.04 & 2.26 & 2.02 & 0.96 & 1.38 & $67.48^{* *}$ \\
\hline Hours per week preparing for class & 17.14 & 9.80 & 28.42 & 10.25 & 40.75 & 15.29 & $91.95^{* * *}$ \\
\hline Hours per week working at a job & 17.12 & 17.18 & 5.49 & 12.90 & 6.03 & 14.25 & $17.43^{* *}$ \\
\hline
\end{tabular}




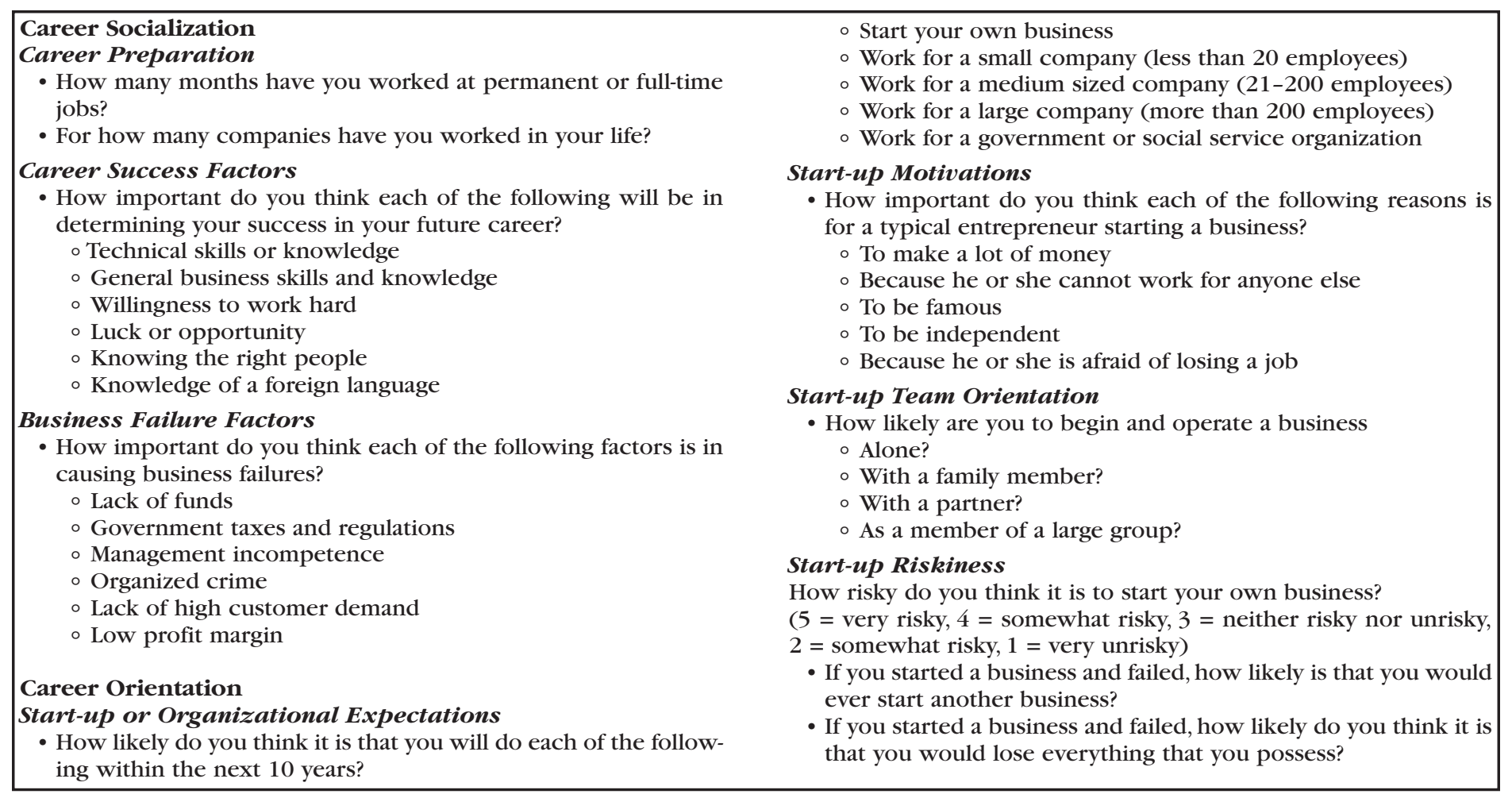

\section{Figure 1. Survey Items}

and decide if they have selected the appropriate career path. On the other hand, U.S. educators may need to stress the value to students of academically learning organizational models and frameworks as an effective way to gain the high grades many top companies value in selecting interview applicants. As career educators point out, it is important for students to gain a broad range of skills and knowledge, including know-how, know-why and know-who (Parker 2002).

Also, flexibility and mode of delivery may be an important factor to consider when designing courses for the U.S. student population, as they continue to make time for work experience. Indeed, online delivery and/or flexible course times have become of more importance to U.S. business students in recent years.

\section{Career Success Factors}

Differences in mean scores across countries were statistically significant for all six career success characteristics (Table 3). The means for these characteristics across all respondents range from 3.32 to 4.89 with most scores well above 4 , suggesting that students in the three countries perceive all six characteristics as somewhat important to very important in their own career success. Ukrainian students were more likely than U.S. or South Korean students to attribute success to knowing the right people and luck or opportunity. American students were more likely to attribute success to hard work and least likely to attribute success to knowledge of a foreign language. Korean students perceive that "knowledge of a foreign language" is one of their three top career success characteristics.

Given the national history and the reported corruption in

\begin{tabular}{|l|r|r|r|r|r|r|r|}
\hline \multicolumn{7}{|c|}{ Table 3. Career Success } \\
\hline Question & \multicolumn{1}{|c|}{ United States } & \multicolumn{1}{|l|}{ Korea } & \multicolumn{1}{l|}{ Ukraine } \\
\hline & Mean & SD & Mean & SD & Mean & SD & F \\
\hline Willingness to work hard & 4.89 & .37 & 4.35 & .86 & 4.53 & .85 & $10.56^{* *}$ \\
\hline General business skills and knowledge & 4.64 & .57 & 3.98 & .81 & 4.59 & .64 & $34.44^{* *}$ \\
\hline Technical skills or knowledge & 4.43 & .74 & 4.39 & .72 & 3.97 & 1.07 & $11.19^{*}$ \\
\hline Knowing the right people & 4.39 & .67 & 4.07 & .87 & 4.62 & .57 & $22.75^{* *}$ \\
\hline Luck or opportunity & 3.99 & .93 & 3.52 & .90 & 4.23 & 1.02 & $20.11^{* *}$ \\
\hline Knowledge of a foreign language & 3.32 & .96 & 4.30 & .76 & 4.35 & .89 & $38.45^{* *}$ \\
\hline
\end{tabular}

*.05 level of confidence; **.01 level of confidence 
the emerging economies of the formerly Soviet bloc countries (Tayler 2001), it is not surprising that Ukraine students see external forces as critical to business success (Table 3). On the other hand, South Korea has emerged from a third-world economy in the 1960s into one of the fastest growing world economies. Korean students appear to perceive their success to flow from hard work and technical skills, and not external factors. The South Korean students' career success profile of emphasizing language and technical skills appears consistent with the realities of the country's geographic and economic context. Geographically, South Korea is between Japan and North Korea, is close to China, and is part of the Pacific Rim. Economically, the country has been a strong trading partner of the United States and has long emphasized language and technical skills in all levels of its educations system.

Americans were the most likely to attribute success to hard work and not surprisingly, given that English has become the language of international commerce, gave significantly lower importance to knowledge of a foreign language (Crystal 1997; Colchester and Aaron 2007). Ukrainian students' perceptions that external factors, such as knowing the right people are more important for career success likely reflect Ukraine's transition to free-market realities, such as the need for bartering and the need to develop connections with individuals who can help maneuver the frequently changing and often uncertain market economy processes, including the important "unofficial economy" that has grown since the country's independence from the Soviet Union (Kaplan 2001; Kristoff 2003; Tayler 2001). Placing importance on external factors of success is also consistent with previous research that suggests Russians have a more external than internal locus of control.

U.S. colleges providing entrepreneurship courses need to recognize the continued strong attraction for larger company career paths among U.S. students. Although U.S. schools have begun emphasizing career placements with smaller and newer firms, much placement activity still occurs with larger firms. Indeed, one focus of entrepreneurship education is not only to prepare future independent business owners, but also to prepare students for roles in corporate entrepreneurship and working for firms that interact with small, entrepreneurial, and closely held ventures as well.

Results also indicate that students in all three countries consider hard work to be a critical factor in their own career success. While this may be true to some extent, it is important for educators to challenge students to distinguish between working hard and working smart, since many individuals advancing in their careers have worked extremely hard only to find their dreams unrealized and options limited.

U.S. student perceptions that knowledge of a foreign language is least important for career success likely reflect the fact that English has become the primary language of busi- ness and may reflect the students' own work experience at this point. Importantly, U.S. educators should be concerned with this finding, since it suggests that U.S. students may miss potential business or career opportunities in which at least some knowledge of other languages is important or where an appreciation for another culture (through language education can provide valuable insights for career success [Babcock and duBabcock 2001]).

Our results about Ukrainian students suggest that educators should focus not only on career placement tasks (e.g., resume and interview preparation), but also on identifying personal attributes and skills for career success. For instance, Ukrainian education could provide self-assessment techniques so students not only identify what personal attributes are important for career success (e.g., internal locus of control), but also evaluate themselves with respect to these attributes. Importantly, long-term career success often means also moving up the organizational hierarchy, where general business skills are typically more important than technical skills. Thus, implications for education relate to increasing Korean students appreciation of how general business skills become more important over time and as individuals pursue higher organization-level careers.

\section{Business Failure Factors}

While American and Korean student responses indicated similar perspectives on the reasons for business failure, Ukrainian students produced a different profile. They attributed failure to government taxes and regulations, which they ranked first, and the American and Korean students ranked fifth (Table 4.) Not surprising, the Ukrainian students perceived that government taxes and regulations were most important in causing venture failure, with management incompetence a second important factor, while both U.S. and South Korean students perceived that lack of funds and management incompetence were both highly important in venture failure.

This result seems to reflect the larger role bureaucracy plays in the Ukraine than in South Korea and the United States (Kaplan 2001; Tayler 2001). In addition, with small independent firms a relatively new phenomenon in the Ukraine, entrepreneurs are still considered a somewhat new social category, often perceived to be linked with criminal organizations. As our research indicates that Ukrainian students identified government regulations, crime, and high taxes as playing significant role in whether a business succeeds or fails, future research might explore the extent to which students in established free market economies understand that different rules apply when dealing with thirdworld economies (Kaplan 2001; Tayler 2001). Likewise, Ukrainian and other third-world students might be studied to see if they realize that integrity and reliability are valued by 
major industrial economies and most developing economies, and that they lead to the kind of long-term business relationships that ultimately lead to mutual wealth creation (Kaplan 2001; Tayler 2001).

\section{Career Orientation Career Expectations}

While students in all three cultures saw a position in a medium-sized company as likely, the Ukrainian students were much more likely to see a small business in their future. This might be explained by the nascent state of capitalism in the Ukraine, where free enterprise is only beginning to take root and where many job opportunities might exist in emerging new small businesses. Significantly, Scott and Twomey (1988) identify lack of employment opportunities among those not holding jobs as an important triggering factor leading to a willingness to consider a wider variety of employment options, including entrepreneurship, than those already holding jobs. Mean scores across all respondents for the five new venture motivations range from 2.44 to 4.43 , and indicate that students in the United States, Korea, and the Ukraine perceive both "independence" and "making a lot of money" as the most important reasons for entrepreneurs to start a new venture (Table 5). Avoiding negative situations (e.g., fear of losing a job and social approval) or to be famous are viewed as less important reasons for entrepreneurs to start a new business across all three countries.
On the other hand, in the United States and South Korea, small business may connote a lack of achievement, and college graduates may not see themselves as wanting to start a career with a small business in a mature market. The survey indicates they would rather start work with a medium or large company that has likely successfully navigated beyond the start-up phase and has established an excellent track record of customer acceptance. Few of the students saw themselves as likely working for the government or other nonprofit organization. Our results also suggest that starting a new venture may be a career choice that Korean and Ukrainian students make earlier in their careers than U.S. students.

U.S. students might perceive that greater work activity (on average 17 hours per week) will lead to jobs after graduation with the types of companies typically active in university placements (e.g., large- and medium-size companies). Furthermore, they may perceive that working for a larger company has the potential to provide a more stable environment and greater financial incentives. Finally, this may also reflect American students' perception that starting a new venture is more risky than perceptions of South Korean and Ukrainian students for starting a new business (Table 8).

If South Korean and Ukrainian students do begin their entrepreneurial ventures earlier than American students, then educators in South Korea and the Ukraine should consider that their students have alternative ways to develop

\begin{tabular}{|l|r|r|r|r|r|r|r|}
\hline \multicolumn{7}{|c|}{ Table 4. New Venture Failure } \\
\hline Question & \multicolumn{1}{|c|}{ United States } & \multicolumn{1}{|l|}{ Korea } & \multicolumn{1}{l|}{ Ukraine } \\
\hline & Mean & SD & Mean & SD & Mean & SD & F \\
\hline Lack of funds & 4.42 & .79 & 4.29 & .75 & 4.09 & .90 & $4.33^{*}$ \\
\hline Management incompetence & 4.41 & .79 & 4.05 & .82 & 4.26 & 1.05 & $3.86^{*}$ \\
\hline Lack of high customer demand & 4.23 & .84 & 3.85 & .92 & 3.82 & .99 & $5.16^{* * *}$ \\
\hline Low profit margin & 4.03 & .91 & 3.62 & .83 & 3.86 & 1.03 & $4.91^{* *}$ \\
\hline Government taxes and regulations & 3.39 & .99 & 3.59 & .84 & 4.37 & .92 & $41.73^{* *}$ \\
\hline Organized crime & 2.65 & 1.15 & 2.52 & 1.03 & 3.41 & 1.07 & $29.34^{* * *}$ \\
\hline
\end{tabular}

${ }^{*} .05$ level of confidence; ${ }^{* *} .01$ level of confidence

\begin{tabular}{|l|r|r|r|r|r|r|r|}
\hline \multicolumn{7}{|c|}{ Table 5. New Venture versus Organizational Career Expectations } \\
\hline Question & \multicolumn{2}{|c|}{ United States } & \multicolumn{1}{|l|}{ Korea } & \multicolumn{1}{l|}{ Ukraine } \\
\hline & Mean & \multicolumn{1}{|c|}{ SD } & Mean & SD & Mean & SD & F \\
\hline Work for a large company & 3.51 & 1.29 & 3.10 & 1.12 & 3.24 & 1.10 & 2.90 \\
\hline Work for a medium-size company & 3.47 & 1.13 & 3.19 & 1.05 & 3.58 & .96 & $5.53^{*}$ \\
\hline Start your own business & 3.35 & 1.40 & 3.14 & 1.27 & 3.56 & 1.18 & $4.29^{*}$ \\
\hline Work for a small company & 2.86 & 1.32 & 2.38 & 1.07 & 3.34 & 1.14 & $25.42^{* *}$ \\
\hline $\begin{array}{l}\text { Work for the government or social } \\
\text { services }\end{array}$ & 2.23 & 1.30 & 2.77 & 1.42 & 3.05 & 2.64 & $3.95^{*}$ \\
\hline
\end{tabular}

$* 05$ level of confidence; ${ }^{* *} .01$ level of confidence 
business and industry experience before starting their new ventures. This is important since key business experience helps ground the entrepreneur in what to expect for longterm success, helps provide important legitimacy for outside support (e.g., funders, suppliers) of the venture and overall strengthens the likelihood of new venture success. For instance, educators in South Korea and the Ukraine could identify proxies for industry and business experience, such as bringing on-board start-up partners with business or startup experience, and choosing business advisors with industry experience. They might also suggest, following Drucker (1985), that students first select an industry in which they are interested in starting a business, and then secure a position with a leader in that field to learn its success strategies. Only then, teachers might suggest an individual is ready to begin a small business in the same field. Similarly, as Alan Timblick (2008), head of the Seoul Global Center has noted, "If Korea is to succeed in the ranks of global economics, its education system should allow students to debate, to be creative in demonstrating their understanding of the subjects studied, and not to be silenced by the notion that the teacher, being senior in rank, must therefore always be right."

\section{Start-up Motivations}

Students in the United States, Korea, and the Ukraine appear to perceive similar reasons for entrepreneurs to start businesses: to be independent or to make a lot of money (Table 6). This result is consistent with the literature on career reasons for new venture creation (Cooper,Woo, and Dunkelberg 1989), and provides a cross-cultural perspective that supports previous single-culture perspectives.

When discussing reasons why students might want to eventually start a business, educators can feel even more confident that culture does not appear to change the main motivations, and indeed educators should help students think through their own reasons for considering a start-up. It is also important that educators help students set realistic expectations for independence and financial growth with respect to starting a business. Not all start-ups have the likelihood of making the entrepreneur independent: many small business owners report that their employees, customers, and suppliers can become a form of "boss" to the entrepreneur.Also, not all start-ups are scalable and/or have the likelihood of making the entrepreneur a lot of money, such as lifestyle businesses or ventures in particular industries.

\section{Start-up Team Orientation}

Both the Ukrainian and U.S. students are likely to start a new venture with a partner or a large group, while the Korean students are likely to start a new venture with a partner or alone. For Ukrainian students, this appears consistent with the importance they place on knowing the right people relative to career success and the market realities during their country's economic transition. Differences in mean scores across countries were statistically significant for all orientations except starting a business alone. Mean scores for the four orientations range from 2.50 to 3.90 with most scores above 3 , suggesting that students in all three countries were moderately sure of whether they would choose to go it alone or with others if they start a business (Table 7.) Results suggest that both the U.S. and the Ukrainian students would more likely choose one or more persons for their start-up teams, while Korean students would more likely choose a solo start-up orientation or choose an individual partner, and were less likely than the U.S. or Ukrainian students to go into business with a family member.

For the U.S. students, individualism is a strong part of their national character. The tendency to want to start a business with others appears consistent with the U.S. emphasis in entrepreneurship education on identifying strong start-up teams, and the market emphasis on the same (e.g., outside support from financial institutions) is often linked to the "team" rather than to an individual.

The South Korean students' tendency to start a new venture either with a partner or alone appears consistent with the country's currently strong entrepreneurship culture, in which many citizens are highly individualistic and not risk averse. Korean students' lesser likelihood of starting a new business with family members seems counterintuitive given the importance placed on family solidarity and values. It may

\begin{tabular}{|l|r|r|r|r|r|r|r|}
\hline \multicolumn{7}{|c|}{ Table 6. New Venture Motivations } \\
\hline Question & \multicolumn{1}{|c|}{ United States } & \multicolumn{1}{|l|}{ Korea } & \multicolumn{1}{l|}{ Ukraine } \\
\hline & Mean & \multicolumn{1}{|c|}{ SD } & Mean & SD & Mean & SD & F \\
\hline To be independent & 4.43 & .74 & 3.84 & 1.07 & 4.21 & .98 & $9.79^{* *}$ \\
\hline To make a lot of money & 4.13 & .73 & 4.13 & .82 & 4.38 & .82 & $4.44^{*}$ \\
\hline Cannot work for anyone else & 3.29 & 1.09 & 2.74 & .95 & 3.32 & 1.19 & $11.52^{* *}$ \\
\hline Afraid of losing a job & 2.70 & 1.15 & 2.53 & 1.12 & 2.83 & 1.31 & 2.38 \\
\hline To be famous & 2.59 & 1.08 & 2.44 & .96 & 2.95 & 1.15 & $8.86^{* *}$ \\
\hline
\end{tabular}

*.05 level of confidence; **.01 level of confidence 
reflect another aspect of the growing individualism among the South Korean population.

While starting a business with others can be a sign of strength, educators of Ukrainian students should help students identify what makes a successful partnership or new venture team, so they strategically create start-up teams that make sense depending on the evolution of the country's economy and the evolution of the individual's venture. On a similar note, given the low priority given to starting a business with family members, educators of South Korean students may need to emphasize key skills for family businesses such as succession planning (Kuratko 2007).

\section{Start-up Riskiness}

Overall, data indicate that the Ukrainian students are less risk averse regarding starting a business than either the U.S. or South Korean students. Given that the United States and Korea have been found to be among the world's most highly entrepreneurial cultures and that entrepreneurial activity has only recently received support in the Ukraine, this finding is somewhat surprising. Pestieau and Possen's research (1992) may help us understand this paradox (Table 8). They found that an abundant labor supply and high taxes are related to higher rates of entrepreneurship, what the 2006 GEM survey identifies as "necessity entrepreneurship," a phenomenon more common in lower income countries than in highincome countries (Bosma and Harding 2006, p. 15). It seems reasonable to assume that the Ukrainian risk perception is mitigated by the harsh economic realities that make entrepreneurship during its transition a necessity for individual and family survival rather than a response to exciting business opportunities (Kristoff 2003; Sarasvathy et al. 1998; Stewart and Roth 2001). The Ukrainian students were the most likely to start a business again after a business failure ( mean = 4.11), and the Americans were the least likely (3.30). Regardless of country, students agreed that it is not very likely that one would lose everything if his or her business fails. In terms of the associated risk involved in starting a business, Americans believed the risk to be the strongest with a mean of 4.07 and the Koreans believed the risk to be weakest with a mean of 3.50 .

As mentioned, overall it appears that Ukrainian students are less risk averse regarding starting a business than either U.S. or South Korean students. In this context, entrepreneurship education should focus Ukrainian students' attention on opportunity identification techniques and on bootstrapping methods for starting new ventures with few resources. In all three countries, educators should also help students learn skills to manage the risks involved in starting a business and develop personal attributes to live with the uncertainty of decisions in new venture context, rather than avoiding risks.

\section{Study Limitations}

First, we examined and analyzed a large number of questionnaire items, thus running the risk of confusing random variation with significant differences across cultures. While we believe our sample size minimizes this risk, we recognize the need for further study to improve the generalizability of our results. Second, as we did not interview students, we could not determine the logic and personal experience behind

\begin{tabular}{|l|r|r|r|r|r|r|r|}
\hline \multicolumn{7}{|l|}{ Table 7. New Venture Team Orientation } \\
\hline Question & \multicolumn{1}{|c|}{ United States } & \multicolumn{1}{|c|}{ Korea } & \multicolumn{1}{|l|}{ Ukraine } \\
\hline & Mean & \multicolumn{1}{|c|}{ SD } & Mean & SD & Mean & SD & F \\
\hline A business with a partner & 3.64 & 1.01 & 3.41 & 1.15 & 3.90 & 1.01 & $7.84^{* *}$ \\
\hline $\begin{array}{l}\text { A business as member of a large } \\
\text { group }\end{array}$ & 3.25 & 1.12 & 3.07 & 1.22 & 3.63 & 1.12 & $9.05^{* *}$ \\
\hline A business with a family member & 3.00 & 1.45 & 2.50 & 1.19 & 3.13 & 1.31 & $9.12^{* *}$ \\
\hline A business alone & 2.75 & 1.40 & 3.21 & 1.38 & 3.11 & 1.44 & 2.46 \\
\hline
\end{tabular}

**.01 level of confidence

\begin{tabular}{|l|r|r|r|r|r|r|r|}
\hline \multicolumn{7}{|c|}{ Table 8. New Venture Riskiness } \\
\hline Question & \multicolumn{1}{|c|}{ United States } & \multicolumn{1}{|c|}{ Korea } & \multicolumn{1}{l|}{ Ukraine } \\
\hline & Mean & \multicolumn{1}{c|}{ SD } & \multicolumn{1}{c|}{ Mean } & SD & Mean & SD & F \\
\hline $\begin{array}{l}\text { Start business after failed business } \\
\text { (1=very unlikely, 5=very likely) }\end{array}$ & 3.30 & 1.20 & 3,84 & .89 & 4.11 & .98 & $16.27^{* *}$ \\
\hline $\begin{array}{l}\text { Lose everything after failed business } \\
\text { (1=very unlikely, 5=very likely) }\end{array}$ & 2.70 & 1.14 & 2.57 & 1.05 & 2.46 & 1.04 & 1.26 \\
\hline $\begin{array}{l}\text { Risk to starting a business } \\
\text { (1=very unlikely, 5=very likely) }\end{array}$ & 4.07 & .85 & 3.50 & .91 & 3.94 & .97 & $32.63^{* *}$ \\
\hline
\end{tabular}

**.01 level of confidence 
some of the questionnaire results. Nor did we include personality measures in this study, so we could not correlate our results across or within cultures based on personality differences. We believe the response comparisons across national contexts is of importance and value for better understanding career expectations, even without the subjective or personality data, while recognizing the potential for much richer explanations of our data with that type of data. Finally, we collected our data from students at one point in time rather than longitudinally so that it might capture the process intention of Dyer's model, so we acknowledge a limitation common to other cross-national studies and that does not take advantage of Dyer's full model of entrepreneurial careers.

\section{Implications for Future Research}

While there are implications for future research related to each of our constructs of interest, we will briefly discuss a few key implications. Future research might be informed by how managers with hiring authority in these three countries actually evaluate college graduates preparation for the world of work. Surveys and interviews could determine if hiring authorities in the Ukraine and South Korea actually favor education achievement over work experience to an extent justified by degree of time these students spend on education versus paid work.

In as much as our data indicate that Ukrainian students are less risk averse regarding starting a business than either U.S. or South Korean students, future research might explore whether this result reflects the lack of jobs in Ukraine's existing businesses or whether it signals optimism about entrepreneurial opportunities in the Ukraine's transition to a free market economy. Likewise, the finding that American students were the least likely to start another business after an entrepreneurial failure challenges the assumption that Americans view new venture failure as an acceptable prelude to new venture success.

As our research indicates that Ukrainian students identi- fied government regulations, crime, and high taxes as playing significant role in whether a business succeeds or fails, future research might explore the extent to which students in established free market economies understand that different rules apply when dealing with third-world economies (Kaplan 2001; Tayler 2001). Likewise, Ukrainian and other third-world students might be studied to see if they realize that integrity and reliability are valued by major industrial economies and most developing economies, and that they lead to the kind of long-term business relationships that ultimately lead to mutual wealth creation (Kaplan 2001; Tayler 2001).

Research might further explore student perceptions across cultures of relative opportunity for success in different sized organizations. For example, Fortune 500 companies in the United States have actually reduced total U.S. employment even as they have expanded their sales bases. Researchers might determine if similar hiring patterns exist among large businesses in the Ukraine and South Korea. It would also be interesting to find out if students were aware of the trends of relative growth and contraction of hiring opportunities in small, medium, and large employment companies.

\section{Conclusion}

Both similarities and differences in undergraduate students' career perceptions across three very different country contexts-United States, Ukraine, and South Korea-and Dyer's Model of Entrepreneurial Career Choice provided a useful framework for extending our understanding beyond antecedents of career choice to "in process" career socialization and career orientation issues. Scholars' future examination of how these process constructs affect actual career progression and success or failure attributes as outlined as later stages in Dyer's model provide exciting future scholarship opportunities, and interesting discussions in entrepreneurship classrooms.

\section{Note}

1.The GEM study included South Korea and the United States, but not Ukraine; similarly, the work ethic study included South Korea and the United States but not Ukraine.

\section{References}

Abetti, P.A., I. Hirvensalo, and M. I. Kapij. 2001. Multi-cultural entrepreneurial ventures in the former Soviet Union: Case studies of Finnish and American approaches in Russia, Ukraine and the Baltics. International Journal of Entrepreneurship and Innovation Management 1, 53-72.

Abrams, R. 2004. What business should I start: Seven steps to discovering the ideal business for you. Palo Alto, California: The Planning Shop.

Ajzen, I. 1985. From intentions to actions: A theory of planned behavior. In J. Kuhl and J. Beckman, eds., Action-control: From cognition to behaviour, Heidelberg: Springer, 11-39.

Akchurin, M. 1992. Red odyssey:A journey through the Soviet Republics. New York: Harper Collins. 
Alange, S., and S. Scheinberg. 1988. Swedish entrepreneurship in a cross-cultural perspective. Frontiers of Entrepreneurship Research 8, 1-15.

Aldrich, H. 1989. Networking among women entrepreneurs. In O. Hagan, C. Rivchun, and D. Sexton, eds., Women-Owned Businesses. New York, NY: Praeger Publishers, 103-132.

Aryee, S., Y. Chay, W.Tan, and H. Hwee. 1994.An examination of the antecedents of subjective career success among a managerial sample in Singapore. Human Relations 47, 5: 487-510.

Autio, E., R. Keeley, M. Klofsten, G. Parker, and M. Hay. 2001. Entrepreneurial intent among students in Scandinavia and in the USA. Enterprise and Innovation Management Studies 2, 2: 145-60.

Autio, E., R. H. Keeley, M. Klofsten, and T. Ulfstedt. 1997. Entrepreneurial intent among students. Testing an intent model in Asia, Scandinavia, and USA. Frontiers of Entrepreneurship Research, Proceedings the 17th Annual Babson College Entrepreneurship Research Conference.

Babcock, R., and B. duBabcock. 2001. Language-based communication zones in international business communication. The Journal of Business Communication 38, 4: 372-412.

Bosma, N., and R. Harding. 2006. GEM 2006 Summary Results. Boston: Babson College.

Boyd, N., and G. S. Vozikis. 1994. The influence of self-efficacy on the development of entrepreneurial career intentions and actions. Entrepreneurship Theory \& Practice, Summer, 63-77.

Brenner, O. C., C. D. Pringle, and J. H. Greenhaus.1991. Perceived fulfilment of organizational employment versus entrepreneurship:Work values and career intentions of business college graduates. Journal of Small Business Management 29, 3 : 62-75.

Cardon, M. S., and R. G. McGrath. 1999. When the going gets tough:Toward a psychology of entrepreneurial failure and remotivation. Frontiers of Entrepreneurship Research. Proceedings the 17th Annual Babson College Entrepreneurship Research Conference, 58-72.

Carter, N. M., W. B. Gartner, and K. G Shaver. 2001. Career reasons variables in the panel study of entrepreneurial dynamics questionnaire. Paper presented at the 2nd Annual Lloyd Greif Symposium on Emerging Organizations, Los Angeles, CA.

Cave, F., S. Eccles, and M. Rundell. 2001. Attitudes towards entrepreneurial failure: a learning experience or an indelible stigma? Frontiers of Entrepreneurship Research. Proceedings the 17th Annual Babson College Entrepreneurship Research Conference.

Chandler, G., and D. Lyon D. 2001. Entrepreneurial reams in new ventures: Composition, turnover and performance. Paper presented at the 2001 Academy of Management, Washington, D.C.

Chay, Y.W. 1993. Special support, individual difference and well being:A study of small business entrepreneurs and employees. Journal of Occupational and Organizational Psychology 66, 4: 285-302.

Clark,T. 2000. Career strategies. Cincinnati: SouthWestern.

Colchester, Max, and Patrick Aaron. 2007. English becomes coin of the realm. Wall Street Journal, B3 (August 6).

Cooper,A. 1986. Entrepreneurship and high technology. In D. Sexton and R. Smilor, eds., The art and science of entrepreneurship. Cambridge, MA: Ballinger Publishing Company.

Cooper,A., and W. Dunkelberg. 1984. A new look at business entry. San Mateo, CA:National Federation of Independent Business.

Cooper, W., C.Y. Woo, and W. Dunkelberg. 1989. Entrepreneurship and initial size of firm. Journal of Business Venturing 5, 4: 317-332.

Crant, M. 1996. The proactive personality scale as a predictor of entrepreneurial intention.Journal of Small Business Management 34, 3: 42-50.

Crystal, David.1997. English as a global language. Cambridge University Press.

Dahles, H. 2005. Culture, capitalism, and political entrepreneurship:Transnational business ventures of the Singapore-Chinese in China. Culture and Organization 11, 1:45-58.

Dominitz, J. and C. Manski. 1996. Eliciting student expectations of the returns to schooling.Journal of Human Resources 31 , 1:1-26.

Drucker, P. 1985. Innovation and entrepreneurship. New York: Harper Row. 
Dyer Jr., W. G. 1994. Toward a theory of entrepreneurial careers. Entrepreneurship:Theory E Practice 19, 2: 7-21.

East European Markets. 1997. Unofficial Economies Studies 17, 17: 6-8.

Florin, Juan, Ranjan Karri, and Nancy Rossiter. 2007. Fostering entrepreneurial drive in business education: An attitudinal approach.Journal of Management Education. 31, 1:17-42.

Forlani, D., and J. Mullin. 2000. Perceived risks and choices in entrepreneurs' new venture decisions. Journal of Business Venturing 15, 4: 305-322.

Friedman, R., M. Kane, and D. B. Cornfield. 1998. Social support and career optimism: examining the effectiveness of network groups among black managers. Human Relations. 51, 9: 1155-1177.

Furnham,A. 1992. Personality at work: The role of individual differences in the workplace. London: Routledge.

Goddard, R. D., and H. J. Weihe. 1992. Attitudes of MBA students toward entrepreneurship: A cross-cultural study. Paper presented at the Annual Eastern Michigan University Conference on Languages and Communication for World Business and the Professions, Ypsilanti, MI.

Golhar, D.Y., and S. P. Deshpande. 1997. HRM practices of large and small Canadianmanufacturing firms. Journal of Small Business Management 35, 3:30-39.

Harris, C. 1995. Cultural impediments to economic reform in the former Soviet states. Journal of Management Inquiry 4, 2 : 140-155.

Hayton, J. C., G. George, and S.A. Zahra. 2002. National culture and entrepreneurship: A review of behavioural research. Entrepreneurship Theory and Practice 26, 4: 33-53.

Heritage Foundation. Index of economic freedom. Retrieved August 7, 2007, from http://www.heritage.org/research/features/ index/country.cfm?id=Ukraine http://www.heritage.org/research/feature/index/country.cfm?id=KoreaSouth http://www. heritage.org/research/features/index/country.cfm?id=United States.

Holland, J. L., 1983. Making vocational choices: A theory of careers. Englewood Cliffs, New Jersey: Prentice-Hall.

Hyatt, J. 1989. Rewriting the book on entrepreneurship. Inc. Magazine 11, 8: 86-93.

Johnson, Charles. 2008. Top producer: On the new ag frontier. http://www.agweb.com/FarmJournal/current/Article. aspx?id=145223.

Kaplan, R. 2001. Looking the world in the eye. The Atlantic Monthly (December): 68-82.

Katz, J.A. 1992.The dynamics of organizational emergence:A contemporary group formation perspective. Entrepreneurship: Theory and Practice 17, 2:97-101.

Katz, J., and W. Gartner. 1988. Properties of emerging organizations. Academy of Management Review 13: 429-441.

Kaufman, P. J., D. H. Welsh, and N.V. Bushmarin. 1995. Locus of control and entrepreneurship in the Russian Republic. Entrepreneurship: Theory and Practice 20, 1: 43-58.

Kilduff, M., and D. Day. 1994. Do chameleons get ahead? The effects of self-monitoring on managerial careers. Academy of Management Journal 37, 4: 1047-1060.

Kolvereid, L. 1996. Prediction of employment status choice intentions. Entrepreneurship Theory and Practice 21, 1: 47-57.

Kristoff, N. 2003. Freedom in second place:A tale of two villages. Cincinnati Enquirer, F2 (August 31).

Krueger, N. 1993. The impact of prior entrepreneurial exposure on perceptions of new venture feasibility and desirability. Entrepreneurship Theory and Practice 17, 1:5-21.

Krueger Jr., N. F., and D. V. Brazeal. 1994. Entrepreneurial potential and potentialentrepreneurs. Entrepreneurship Theory and Practice 18, 3:91-105.

Kuratko, D. F. 2007. Entrepreneurship: theory, process, practice, 7th ed. Cincinnati: South-Western.

Kuratko, D. F., and R. M. Hodgetts. 1995. Book reviews. Organizational Dynamics 24, 1: 84-86.

Kuratko, D. F., and R. M. Hodgetts. 2004. Entrepreneurship. London:Thomson Publishing.

Lee, Soon Hoo, and Poh Kam Wong. 2004. An exploratory study of technopreneurial intentions:A career anchor perspective. Journal of Business Venturing 19:1,7-28.

Lewis, P., and G. Lancaster. 2007. Predictive strategic marketing management decisions in small firms:A possible Bayesian solution. Management Decision 45, 6: 1038-1057. 
Lussier, R. N. 1995. A nonfinancial business success versus failure predication model for young firms. Journal of Small Business Management 33, 1:8-20.

Lussier, R. N., and S. Pfeifer. 2001. A cross-national prediction model for business success. Journal of Small Business Management 39, 3: 228-239.

Luthans, F, S.A. Rosenkrantz, and D. Welsh. 1992. An empirical analysis of the activities of effective Russian manufacturing managers. In Proceedings of the National Academy of Management. Eds. L. R. Jauche and J. L. Wall. Madison, WI: Omni Press, 112-116.

Matthews, C., and S. Moser. 1995. Family background and gender: Implications for interest in small firm ownership. Entrepreneurship and Regional Development 7, 4:365-377.

Miner, J. B. 1990. Entrepreneurs, high growth entrepreneurs and managers: contrasting and overlapping motivational patterns, Journal of Business Venturing 5, 4: 221-234.

Moore, R.A. 1989. A cross cultural research project: Using the mail questionnaire. The Quarterly Review of Marketing 14, 3 : $14-17$.

Moore, D. P. 2002. Bounderyless transitions: global career concepts. In R. J. Burke and D. L. Nelson, eds., Advancing Women's Careers. London: Blackwell, 245-261.

O'Reilly, C.A., and J.A. Chatman. 1994. Working smarter and harder:A longitudinal study of managerial success. Administrative Science Quarterly 39, 4: 603-627.

Parker, P. 2002. Working with the intelligent career model.Journal of Employment Counseling 39, 2: 83-96.

Parasuraman, S., Y. Purohit, V. Godshalk, and N. Beutell 1996. Work and family variables, entrepreneurial career success, and psychological well-being. Journal of Vocational Behavior 48, 275-300.

Pestieau, P., and U. Possen. 1992. How do taxes affect occupational choice? Public Finance 47, 1: 108-119.

Ramstad, Evan 2007. Candidate rallies Koreans behind a grandiose project. Wall Street Journal, p. 1, cols 3-4 (December 10).

Reid, G. C., and J.A. Smith. 2000. What makes a new business start-up successful? Small Business Economics 14, 3: 165.

Reynolds, P. D., M. Hay, W. D. Bygrave, S. M. Camp, and E. Autio. 2000. Global entrepreneurship monitor: Executive report. Kauffman Center for Entrepreneurial Leadership at the Ewing Marion Kauffman Foundation.

Reynolds, P. 1995. The truth about start-ups. Inc. Magazine 17, 2: 23-25.

Salter, C. L., J. J. Hobbs, J. H. Wheeler, and J.T. Kostbade. 2000. Essentials of world geography, third edition. Fort Worth: Saunders College Publishing.

Sarasvathy, D. K., H.A. Simon, and L. Lave. 1998. Perceiving and managing business risks: Differences between entrepreneurs and bankers. Journal of Economic Behavior and Organization 33, 2: 207-223.

Scheinberg, S. and I. C. MacMillan. 1988. An 11 country study of motivations to start abusiness. Frontiers of Entrepreneurship Research, Proceedings the 17th AnnualBabson College Entrepreneurship Research Conference, 669-687.

Scherer, Robert F., James D. Brodzinski, and Frank A. Wiebe, Frank A. 1990. Entrepreneur career selection and gender: A socialization approach. Journal of Small Business Management 28 April, 37-44.

Scott, M. G., and D. F.Twomey. 1988. The long-term supply of entrepreneurs: students' career aspirations in relation to entrepreneurship. Journal of Small Business Management 26, 4:5-13.

Segal, G., D. Bopria, and J. Shoenfeld. 2002. Using social cognitive career theory to predict self-employment goals. New England Journal of Entrepreneurship 5, 2: 47-56.

Sexton, D., and H. Landstrom. 2000. The Blackwell handbook of entrepreneurship. Malden, MA: Oxford Press.

Shane, S., and L. Kolvereid. 1995. National environment strategy and new venture performance:A three country study. Journal of Small Business Management 33, 2:37-51.

Sinclair, Robert. 2008. The first step toward empirical support of the entrepreneurial career. Paper presented at the PSED Symposium, Greenville, South Carolina (November).

Spector, P. E., C. L. Cooper, J. I. Sanchez, M. O’Driscoll, K. Sparks, P. Bernin, A. Buessing, P. Dewe, P. M., Hart, L. Lu, K. Miller, L. R. de Moreas, G. M. Ostrognay, M. Pagon, H. Pitariu, S. Poelmans, P. Radhakrishnan, V. Russinova, V. Salamatov, J. Salgado, S. Shima, L. S. Oi, J. B. Stora, M. Teichmann, T. Theorell, P.Vlerick, M. Westman, M. Widerszal-Bazyl, P.T. Wong, and S. Yu. 2001. Do 
national levels of individualism and internal locus of control relate to well-being:An ecological level international study. Journal of Organizational Behavior 22, 8: 815-832.

Stephens, G. K., B. Szajna, and K. Broome. 1998. The career success expectation scale:An exploratory and confirmatory factor analysis. Educational and Psychological Measurement 58, 1: 129-141.

Stewart Jr., W. H., and P. L. Roth. 2001. Risk propensity differences between entrepreneurs and managers:A meta-analytic review. Journal of Applied Psychology 86, 1: 145-153.

Sykes, H. B., and D. Dunham. 1995. Critical assumption planning: A practical tool for managing business development risk. Journal of Business Venturing 10, 6: 413-425.

Tayler, J. 2001. Russia is finished. The Atlantic Monthly (May): 35-52.

Tiessen, J. H. 1997. Individualism, collectivism, and entrepreneurship:A framework for international comparative research. Journal of Business Venturing 12, 5:367-385.

Timblick, Alan. 2008. Emphasis on hierarchy hampers globalization.www.koreatimes.co.kr/www/news/special/ 2008/11/178_34990.html.

Timmons, J.A. 1986. Growing up big: Entrepreneurship and the creation of high-potential ventures. In D. Sexton and R. Smilor, eds., The art and science of entrepreneurship. Cambridge, MA: Ballinger Publishing Company.

Timmons, J.A. 1999. New venture creation: Entrepreneurship for the 21st century. Boston: Irwin/McGraw-Hill.

Transparency International. Retrieved August 7, 2007 from http://www.transparency.org/news_room/in_focus/ 2006/bpi_2006.

Ukrainian News Agency. 2008. Courts, police most corrupt structures for Ukrainians polls show. (11 November). http://www.ukrinform.ua/eng/order/?id=144983\&ulq=Horshenin corruption.

Van Clieaf, M. S. 1991. In search of competence: Structured behaviour interviews. Business Horizons 34, 2: 51-56.

Wayne, S., R. Liden, M. Kraimer, and I. Graf. 1999. The role of human capital,motivation and supervisor sponsorship in predicting career success. Journal of Organizational Behavior 20, 5: 577-595.

Webb, C. L. 2001. U.S. Workers Putting in Long Hours: Report Says America Tops Industrialized World. The Washington Post, sec E, 01 (September 4).

World Bank. 2008. http://www.doingbusiness.org/economyrankings/.

Zhao, H., S. Seibert, and G. Hills. 2005, November.The mediating role of self-efficacy in the development of entrepreneurial intentions. Journal of Applied Psychology 90, 6: 1265-1272.

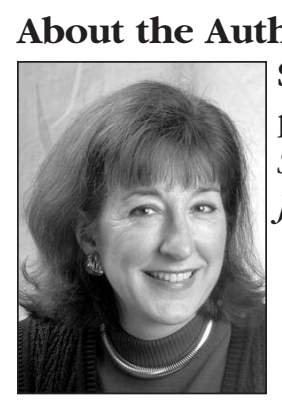

\section{MEjE}

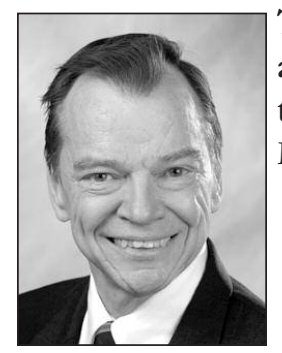

Thomas Clark (clarkt@xavier.edu), who earned his Ph.D. at Indiana University, is a professor of management and entrepreneurship at Xavier University. His work has appeared in Entrepreneurship Theory \& Practice and the Journal of Small Business Strategy. He has served on the editorial board of Journal of Small Business Management, and directed three nationally award-winning SBIDA reports. 


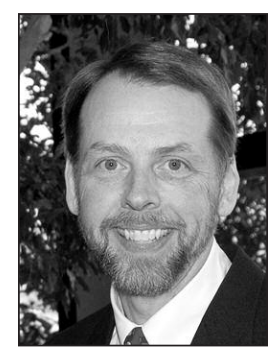

Charles H. MatThews (charles.matthews@uc.edu) is a distinguished teaching professor and executive director of the Center for Entrepreneurship Education and Research and director of the Small Business Institute at the University of Cincinnati. His research interests include strategic planning, decision-making, and leadership succession in small, entrepreneurial, and closely held firms.

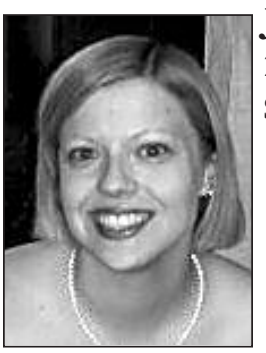

JULIE STEWART (justewxu@hotmail.com) was awarded a masters degree from the University of Cincinnati in 2007. She teaches communications classes at Xavier University. Previously a district executive for the Boy Scouts of America, she is currently pursuing a Ph.D. at the University of Cincinnati.

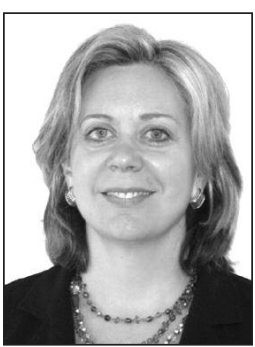

CANDACE L. Gunnarsson (candaceg@s2stats.com) is owner-operator of S ${ }^{2}$ Statistical Solutions, Inc., founded in 1999. $\mathrm{S}^{2}$ Statistical Solutions, Inc. is a consulting firm in Cincinnati, Ohio, that performs data mining, statistical analyses, and economic evaluations for medical device and pharmaceutical companies. Dr. Gunnarsson has consulted for many medical device, diagnostics, and pharmaceutical companies both in and outside of the United States. 